\title{
Characterization of citrus farms production systems used in Rio Grande do Sul, Brazil
}

\author{
Manuela Sulzbach ${ }^{1}$, Roberto Pedroso de Oliveira ${ }^{2}$, Paulo Dabdab Waquil ${ }^{3}$, \\ Eduardo Augusto Girardi ${ }^{4}$, Mateus Pereira Gonzatto ${ }^{1}$, Gerson Nestor Böettcher ${ }^{1} \&$ \\ Sergio Francisco Schwarz ${ }^{1}$
}

\section{SUMMARY}

Brazil is the second world largest citrus producer, and the State of Rio Grande do Sul (RS) is the sixth largest national producer, with about 505 thousand tons of citrus fruits in 2014. The state's citrus chain has different characteristics, consisting mostly of small family-based farms. This study aimed to diagnose the production system used in Rio Grande do Sul, through a structured questionnaire composed of 19 questions of closed and open answers to 163 growers, residents in 35 locations in the RS, belonging to the regions Vales do Caí and Taquari, Alto Taquari, Alto Uruguai, Noroeste, Serra do Nordeste and Fronteira Oeste. The selected locations have the citrus industry as an important activity for the local economy and the number of interviewed farmers varied according to the existing cultivated area in each. The interviewed farmers in each city were selected by non-probability sampling and convenience, and the information obtained was planned, generating quantitative and qualitative data. There were features prevalent in the visited farms, such as aging of the rural population, low level of education of growers, mainly family labor employment and concern about the shortage of work observed in rural areas. However, they presented long experience in the citrus activity and obtain good yields, similar to the average recorded in the State.

Index terms: citrus, diagnosis, family farming.

\section{Caracterização do sistema de produção em propriedades citrícolas do Rio Grande do Sul}

\section{RESUMO}

O Brasil é o segundo maior produtor mundial de citros, sendo o Rio Grande do Sul (RS) o sexto maior produtor nacional, com cerca de 505 mil toneladas de frutas cítricas em 2014. A cadeia citrícola gaúcha possui características diferenciadas, constituída em sua maioria por pequenas propriedades de base familiar. O presente estudo objetivou a realização de um diagnóstico do sistema produtivo por meio da aplicação de questionário estruturado composto por 19 questões de

\footnotetext{
${ }^{1}$ Programa de Pós-Graduação em Fitotecnia, Departamento de Horticultura e Silvicultura, Faculdade de Agronomia, Universidade Federal do Rio Grande do Sul - UFRGS, Porto Alegre, RS, Brazil

${ }^{2}$ Embrapa Clima Temperado, Pelotas, RS, Brazil

${ }^{3}$ Departamento de Ciências Econômicas, Faculdade de Ciências Econômicas, Universidade Federal do Rio Grande do Sul UFRGS, Porto Alegre, RS, Brazil

${ }^{4}$ Embrapa Mandioca e Fruticultura, Cruz das Almas, BA, Brazil

Corresponding author: Manuela Sulzbach, Programa de Pós-Graduação em Fitotecnia, Departamento de Horticultura e Silvicultura, Faculdade de Agronomia, Universidade Federal do Rio Grande do Sul - UFRGS, Av. Bento Gonçalves, 7712, CEP 91540-000, Porto Alegre, RS, Brazil. E-mail: manuela.sulzbach@ufrgs.br
} 
resposta aberta e fechada a 163 citricultores, residentes em 35 municípios do RS, pertencentes aos Vales dos Rios Caí e Taquari, Alto Taquari, Alto Uruguai, Noroeste, Serra do Nordeste e Fronteira Oeste. Os municípios selecionados têm a citricultura como atividade de importância para a economia local e o número de entrevistados variou conforme a área cultivada existente em cada um deles. Os entrevistados em cada município foram escolhidos por amostragem não probabilística e por conveniência, sendo as informações obtidas planificadas, gerando dados quantitativos e qualitativos. Verificaram-se características predominantes nas propriedades visitadas, como envelhecimento da população rural, baixa escolaridade dos citricultores, emprego de mão de obra essencialmente familiar e preocupação acerca da escassez de mão de obra observada no meio rural. Contudo, foi constatada grande experiência na atividade citrícola e obtenção de bons rendimentos, semelhantes à média registrada no Estado.

Termos de indexação: citricultura, diagnóstico, agricultura familiar.

\section{INTRODUCTION}

In 2014, Brazil was the world's leading citrus producer (19 million tons), second only to China (33 million tons) (FAO, 2016). Nowadays, Brazil is the world's leading producer of orange, with an estimated production of 16 million tons in 2015 (AGRIANUAL, 2016). The state of Rio Grande do Sul accounts for only $3 \%$ of the national citrus production, with a volume of 505 thousand tons per year, and it is responsible for $17 \%$ of the Brazilian production of mandarins (IBGE, 2016).

Citrus is cultivated in approximately 798 thousand hectares of Brazil, of which slightly over 40 thousand hectares is in the state of Rio Grande do Sul. The area of land for citrus farming in the state consists of 26 thousand hectares planted with orange trees, 13 thousand cultivated with mandarin trees and approximately 1.4 thousand hectares are planted with lemon and lime trees (IBGE, 2015).

Citrus trees were first introduced in Rio Grande do Sul by the Azorean immigrants and their descendants, in Vale do Taquari region during the eighteenth century, and by the Germanic immigrants, in the Vale do Caí, at the end of the twentieth century (João, 2010). According to the same author, the citrus industry is very important for the economic, social and environmental development of several municipalities. In Rio Grande do Sul, citrus trees are mostly cultivated in small lands, with an estimated planted area of 2.8 hectares, and most of the workforce is represented by family worker there are approximately 15 thousand rural producers (João, 2010; EMATER/RS, 2015).

Currently, the state of Rio Grande do Sul contains several major citrus-producing areas, with particular emphasis on the following regions: Vales do Caí and Taquari, where most of the production is of fruit (in natura consumption), especially of mandarins (João, 2010), and the regions of Alto Uruguai and Fronteira Oeste (Oliveira et al., 2010).
According to the authors, the expansion into these new areas occurred in the 1990s, when, in Alto Uruguai, the family farming citriculture was predominant, such as in the Vales do Caí and Taquari, where most of the production is of oranges aimed for industrial juice processing, and in the last region the implementation of large-scale business orchards for the in natura fruit trade has been observed. Another sector that was highlighted was that of the commercialization of green fruits aimed for the extraction of essential oils, of which Brazil is one of the main suppliers of the product in the world market, alongside India, China and Indonesia (Bizzo et al., 2009; Zulian et al., 2013). In Rio Grande do Sul, this sector has grown mainly in relation to the extraction of essential oils from the mandarin peel and with the installation of extracting industries in Vale do Caí.

Given the lack of updated information on the local citrus farms production systems, this study aimed to characterize the rural properties of several municipalities of Rio Grande do Sul that are mainly dedicated to the production of citrus, in order to draw a profile of the citrus growers involved in the activity, as well as to distinguish the main obstacles to the state's citriculture in the view of the producers. This information is of utmost importance, due to the fact that it grants greater knowledge and awareness of the production chain and, therefore, would enable the development of more realistic analysis and management strategies, in addition to assistance programs tailored to the needs of the citrus growers.

\section{MATERIAL AND METHODS}

Data was collected using a structured questionnaire which was especially developed for the research. The questionnaire was applied to the target group of the study during field visits to rural households during the 
period of August 2015 to December 2015. Most visits were accompanied by technicians and extension workers of Empresa Brasileira de Pesquisa Agropecuária (EMBRAPA), Universidade Federal do Rio Grande do Sul (UFRGS), Ministério da Agricultura, Pecuária e Abastecimento (MAPA) and Empresa de Assistência Técnica e Extensão Rural do Rio Grande do Sul (EMATER/RS). A total of 163 citrus growers from 35 municipalities of Rio Grande do Sul were interviewed for this study.

The municipalities to be visited were defined according to the relevance of the citrus sector to the local economy, where as the number of respondents per municipality was defined according to the area planted with citrus.

The respondents were selected by non-probability sampling and convenience, since random sampling was not used. The selection was also based on feasibility, the individuals were chosen according to their proximity or availability (Duarte, 2008). The sampling method to calculate the required sample size per municipality was determined on the basis of the following strategy: only one citrus grower was interviewed in municipalities with up to 100 hectares of planted area; three citrus growers were interviewed in municipalities of 101 to 500 hectares of planted area; 501 to 700 hectares at least four respondents; 701 to 1.300 hectares at least six respondents; ten respondents for 1.301 to 1.600 hectares; 14 respondents for 1.601 to 1.900 hectares; and, for over 1.900 hectares, 18 people responded.

The locations were selected according to their relevance to the citrus industry, in the regions: Vales dos rios Caí and Taquari: Barão, Brochier, Harmonia, Maratá, Montenegro, Pareci Novo, Portão, São José do Hortêncio, São José do Sul, São Sebastião do Caí, Triunfo and Tupandi; in Alto Uruguai: Alpestre, Aratiba, Constantina, Itatiba do Sul, Liberato Salzano, Marcelino Ramos, Mariano Moro, Maximiliano de Almeida, Planalto, Severiano de Almeida and Três Arroios; of Serra do Nordeste: Bento Gonçalves, Caxias do Sul and Veranópolis; of the Noroeste: Bozano, Catuípe, Ijuí and Santo Cristo; in Alto Taquari: Anta Gorda and Arvorezinha; of the Sul: Pelotas; of Fronteira Oeste: Rosário do Sul and Uruguaiana.

This study is based on an open-ended and structured questionnaire, made up of 19 pre-established questions: 1) identity; 2) age; 3) education; 4) telephone number; 5) zoning designation; 6) municipality; 7) farm location; 8) farm size; 9) experience in the industry; 10) farm labor; 11) productivity; 12) production destination; 13) marketing; 14) composition of the orchard (cultivars and rootstocks); 15) organization of plantation; 16) origin of the citrus trees; 17) type of fertilization; 18) pests and diseases; and 19) limiting factors to the production according to the interviewee's opinion.

The data collected was planned in Microsoft Office Excel, thus generating graphs and charts. The variability of the samples was assessed, calculating the amplitudes (maximums and minimums), arithmetic means and standard deviations for the quantitative data and the number of citations was evaluated for the qualitative data.

\section{RESULTS AND DISCUSSION}

According to the results obtained, it was observed that the state's citrus industry follows the ageing pattern of the rural population verified in the last few decades, in both developed and developing countries alike, thus constituting a major challenge to the rural and urban areas (Mera \& Mielitz Netto, 2014). Among the respondents, only $11 \%$ were under 30 years of age; $16 \%$ from 31 to 40 years old; $31 \%$ from 41 to 50 years old, $24 \%$ between 51 to 60 years of age and $18 \%$ of the respondents were over 60 (Figure 1). Hence, only $27 \%$ of the respondents were in the under 40 age group. The ageing of the farming population occurs mainly due to the low rural succession observed, considering that the perpetuation of family farming usually occurs with one of the family members becoming the successor of the productive unit (Carneiro, 2001; Godoy et al., 2009).

In relation to the education level of the interviewed farmers: $48 \%$ of the interviewed farmers did not finish primary school and $17 \%$ completed their basic education; $4 \%$ studied until high school, but did not complete

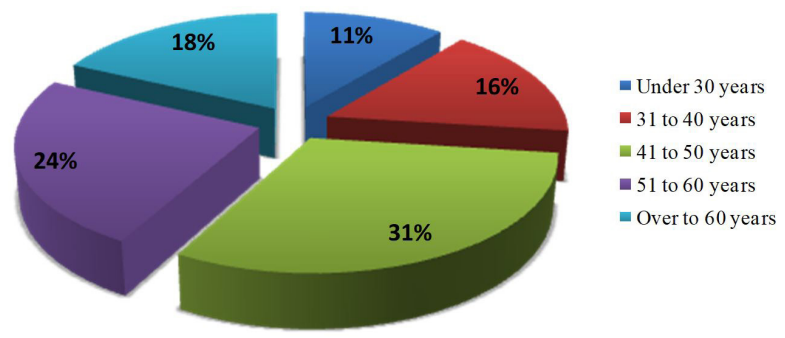

Figure 1. Citrus growers were interviewed in five age groups (under 30 years, 31 to 40 years, 41 to 50 years, 51 to 60 years and over 60 years), according to the percentage obtained for each of them. State of Rio Grande do Sul, $2015(\mathrm{n}=163)$. 
secondary school and $18 \%$ of the respondents graduated from middle school; $3 \%$ of the farmers completed an agricultural technical course; $2 \%$ had an incomplete higher education; and $8 \%$ had already graduated in higher education. Therefore, $65 \%$ of the farmers interviewed did not study beyond primary education, thus hindering their access to information and also affecting their understanding of the importance of some recommended management strategies. In a similar study, Panzenhagen (2004) found that approximately $68 \%$ of the men of Vale do Caí (RS) had completed their elementary education. Still according to the IBGE (2006), only 4,9\% of the family farmers of the state are professionally qualified, that is, they have higher education in related areas. However, in terms of their experience with the activity, the average amount of years of experience among the interviewees was of 22 years, with a minimum of two and a maximum of 60 years of experience in citrus production.

Regarding the farm's labor productivity, $66 \%$ of the rural properties are operated by farm families, mainly using their own labor. The labor employed by $66 \%$ of the interviewees was of only family origin, usually performed couple who resided in the farm; $20 \%$ of family labor and temporary workers who are hired only at times of greater demand, such as thinning and harvesting; $4 \%$ commercial family farmers who may employ one or two permanent, non-family workers; $8 \%$ workforce composed only of hired non-family workers, both permanent and temporary and in $2 \%$ the workforce was of only permanent workers (Figure 2).

By accounting all the situations in which family workforce is involved, this form of labor was used in $90 \%$ of the respondent's properties. As a result of a

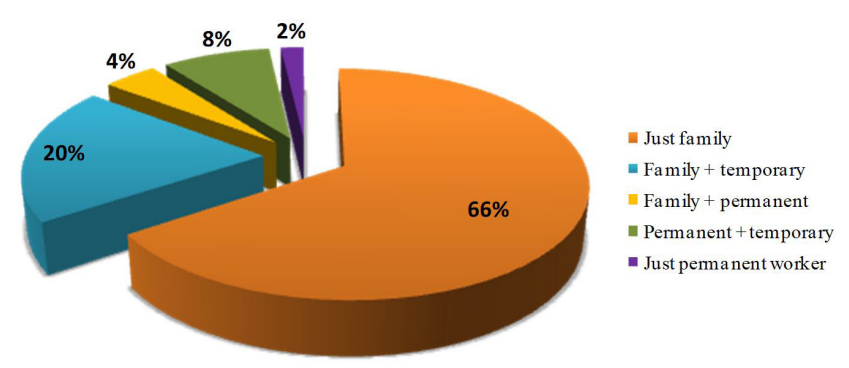

Figure 2. Categorization of labor employed according to type (just family, family + temporary worker, family + permanent worker, permanent + temporary workers, just permanent worker), and percentage of use. State of Rio Grande do Sul, 2015 ( $\mathrm{n}=163)$. study conducted by Bonine \& João (2002), with 84 citrus growers in the Vale do Caí, 64\% used only family labor, while $27 \%$ would hire one or two people a year.

Regarding the size of the agricultural properties: $27 \%$ are farms of up to 10 hectares, $54 \%$ owned properties of 11 to 30 hectares; $12 \%$ owned farms of 31 to 50 hectares, $4 \%$ farms of 51 to 100 hectares; and only $3 \%$ consisted of farms of over 100 hectares (Figure 3). Thus, 94\% of the respondents owned properties with an area of less than 50 hectares. According to the Instituto de Geografia e Estatística (IBGE, 2006), the average size of the land holdings characterized as family farms in Rio Grande do $\mathrm{Sul}$ is from 16 to 30 hectares per establishment. According to João (2010), the state's citriculture is basically developed on small lands and with the predominant use of family labor, which is consistent with the results obtained in this study.

The average size of the properties owned by the respondents varied according to the region where it was located, given that the Fronteira Oeste of the state was characterized by larger properties, with an average size of 75 ha per establishment. In Alto Uruguai, the average size was 21.5 ha, and in the Vale do Caí, the average was 17.5 hectares per establishment. As for the average cultivated area, the average planted area of the citrus growers who are mainly dedicated to the production of oranges is $6.3 \mathrm{ha}$, and 7.7 ha of bearing orchards for the mandarins producers. The average production level for the respondents was 194 tons per productive unit, and the average yield of 16 tons per hectare, data similar to those obtained by a survey conducted by EMATER/RS (2015), which indicates an average yield of 13 tons per hectare for the citrus fruit in the State.

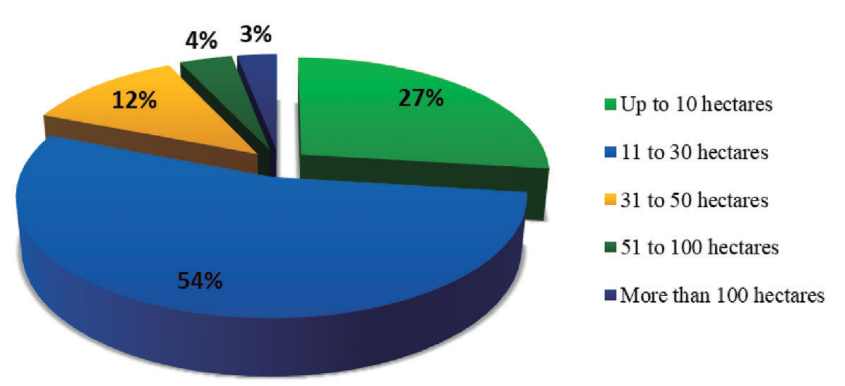

Figure 3. Total percentages of properties with dimensions: up to 10 hectares; 11 to 30 hectares; 31 to 50 hectares; 51 to 100 hectares; above 100 hectares. State of Rio Grande do Sul, $2015(\mathrm{n}=163)$. 
The main destination of the production among the interviewees was the fruit market for in natura consumption $(65 \%)$, followed by fruit for the juice industry $(28 \%)$ and fruit for the extraction of essential oil (7\%). While there are several variations across the producing regions, is was observed that there is a prevalence of fruits destined to the in natura consumption and to the fresh market in the Vales do Caí and Taquari (94\%) and in the Fronteira Oeste $(100 \%)$, while in Alto Uruguai, fruits were mainly intended for the industry (98\%). The most common marketing approach was via traders (113 citations), followed by sales of the product to the buyers either directly or by direct delivery to establishments (66 citations) in addition to joint selling via associations and cooperatives (33 citations). It should be noted that, for the analysis of these data the number of citations was used, since most producers use more than one way of marketing their production. When the educational background is associated with the marketing method, it was observed that the respondents with a higher level of education (agricultural technician or higher education), would preferentially commercialize their products directly with the buyer (65\%), strategy that yields the citrus grower with higher profits.

Most of the afore mentioned citrus trees were originated in the Vale do Caí, a region that contains a large number of nurseries, followed by citrus trees coming from nurseries of Santa Catarina State and that are very employed in the municipalities of Alto Uruguai. As for diversification of rootstocks, $74 \%$ of respondents' cultivation was exclusively on Poncirus trifoliata (L.) Raf., $8 \%$ only on
Rangpur lime (Citrus limonia Osb.) and 1\% on Swingle citrumelo plants (Citrus paradisi Macf. x P. trifoliata). However, $10 \%$ of the producers cited the combination of P. trifoliata and Rangpur; 4\% of P. trifoliata, Rangpur and Swingle; and 3\% of only Rangpur and Swingle (Figure 4). Schäfer et al. (2001) found that more than $90 \%$ of the seedlings commercialized at that time used $P$. trifoliata as a rootstock. In this study, it was observed that the monoculture of $P$. trifoliata has changed the situation; there was a slight increase in the use of other rootstocks in the field. According to Oliveira \& Scivittaro (2011), in Rio Grande do Sul, P.trifoliata is the preferred rootstock in citrus growers of the Vales do Caí, Taquari, and Metade Sul, because in addition to inducing a good improvement in fruit quality, it is also highly resistant to the cold. It was also found to be tristeza immune, nematode and phytophthora resistant and it is also tolerant to sudden death in citrus. However, the range of genetic material in relation to rootstocks is still very limited in Brazil, especially in the state of Rio Grande do Sul, and the lack of diversification confers vulnerability to these cultivations, which may be decimated in the event of any disease to which $P$. trifoliata is susceptible to (Schäfer et al., 2001). Unlike what was observed with the rootstocks, diversification of the cultivars is significant among the respondents: $17 \%$ use only one cultivar, but $32 \%$ up to three different cultivars, $45 \%$ of four to seven cultivars and $6 \%$ over eight cultivars. The most diversified productions are grown in the Fronteira Oeste and in the Vales dos Rios Caí and Taquari, while the largest number

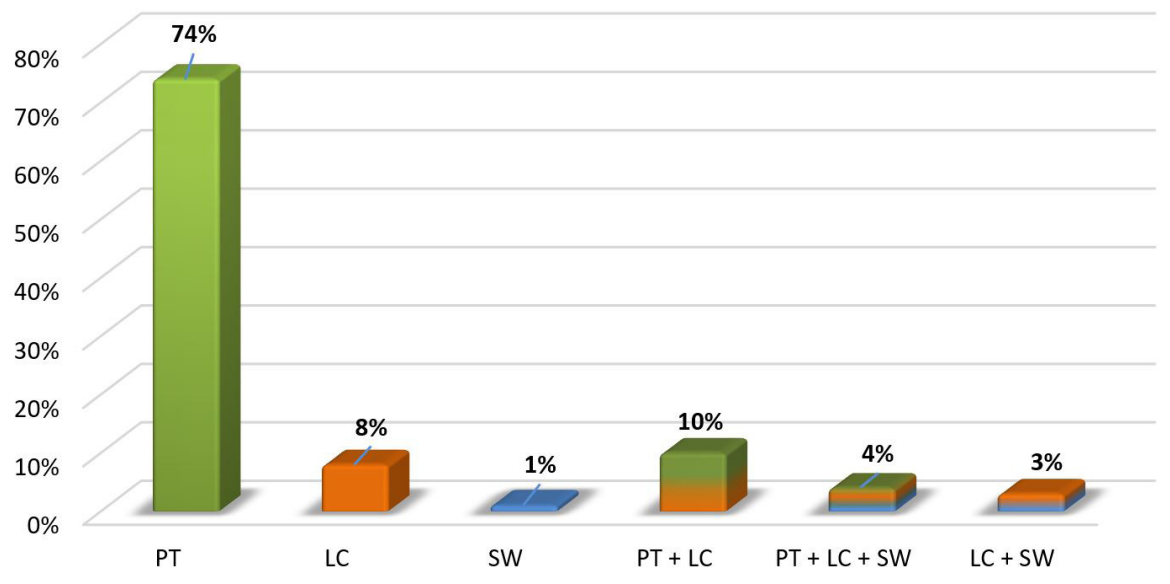

Figure 4. The percentage of use of rootstocks: PT (Poncirus trifoliata only), LC (Cravo lemon only), SW (Swingle citrumeleiro only), PT + LC (P. trifoliata +1 . Cravo), PT + LC $+\mathrm{SW}($. trifoliata +1 . Cravo + C. Swingle $)$, $\mathrm{LC}+\mathrm{SW}$ (1. Cravo + C. Swingle). State of Rio Grande do Sul, $2015(\mathrm{n}=163)$. 
of citrus growers producing only one cultivar was recorded in Alto Uruguai, where $36 \%$ of the respondents based their production on Valencia's orange cultivar. The most cited cultivars of mandarins were Montenegrina, Caí and Pareci (Citrus deliciosa Ten.), Ponkan (Citrus reticulata Blanco), Okitsu (C. unshiu Marc.) and the Murcott tangor (C. reticulata $\mathrm{x}$ Citrus sinensis Osb.). As for the orange trees $(C$. sinensis), cultivar Valencia was predominant, followed by the navel orange cultivars Monte Parnaso and Bahia.

In a study carried out by Bonine \& João (2002), the most widely cultivated varieties of mandarin trees all belonged to the Common group (Montenegrina, Caí and Pareci), Murcott and Ponkan; and orange trees Valencia, Bahia and Céu, demonstrating that the preference for these cultivars has prevailed. According to Oliveira et al. (2010), Rio Grande do Sul is the State with the greatest diversification of canopy-cultivars, although Valencia orange and Montenegrina mandarin are still prevalent.

As for the productive system, $4 \%$ of the respondents were organic producers, $31 \%$ were conventional producers who made little use of agrochemicals (two to a maximum of five sprayings per season, including fungicides and insecticides), and $65 \%$ of them were conventional producers with great use of inputs. A large proportion of the interviewed farmers employ both mineral and organic fertilization, the latter composed mostly of poultry waste (aviary bedding) located near the producing region.

Phytosanitary issues are major bottlenecks to the citrus industry, in addition to being responsible for the increase in production costs and, often, for significant reductions in the productivity of orchards, which can be attributed to the economic costs of implementing new care-taking strategies, and overall tree loss creating a loss of revenues. The citrus growers that were interviewed in this survey considered the main pests and diseases that have infected their orchards. For the analysis of this information, they were divided into two groups, according to the productive focus: producers of oranges and of tangerines. For the orange producers, the main pests reported were: the citrus black spot (Guignardia citricarpa), citrus canker (Xanthomonas citri pv. citri), fruit fly (Anastrepha fraterculus), the citrus rust mite (Phyllocoptruta oleivora) and the citrus leafminer (Phyllocnistis citrella); for the mandarin growers, the main pests were: citrus canker, fruit fly, citrus leafminer and the black aphid (Toxoptera citricidus) (Figure 5).

Nava et al. (2011) affirm that the citrus canker, fruit fly, citrus leafminer, aphids, and the citrus rust mite are the five key citrus-plague pests across the country and, most of the times, directly responsible for falling production. This data corroborates with those found in this study. According to Ueno (2011), citrus canker is the main bacterial disease in Rio Grande do Sul; it was the second most frequently mentioned throughout the survey. However, the citrus black spot disease was what the great majority of the interviewed farmers referred to when inquired and it is very significant in the country, as it represents the greatest threat to citrus orchards in the state. This disease causes serious damage to Montenegrina and Murcott fruits, devaluing them commercially and making it impossible to commercialize them as table fruits.

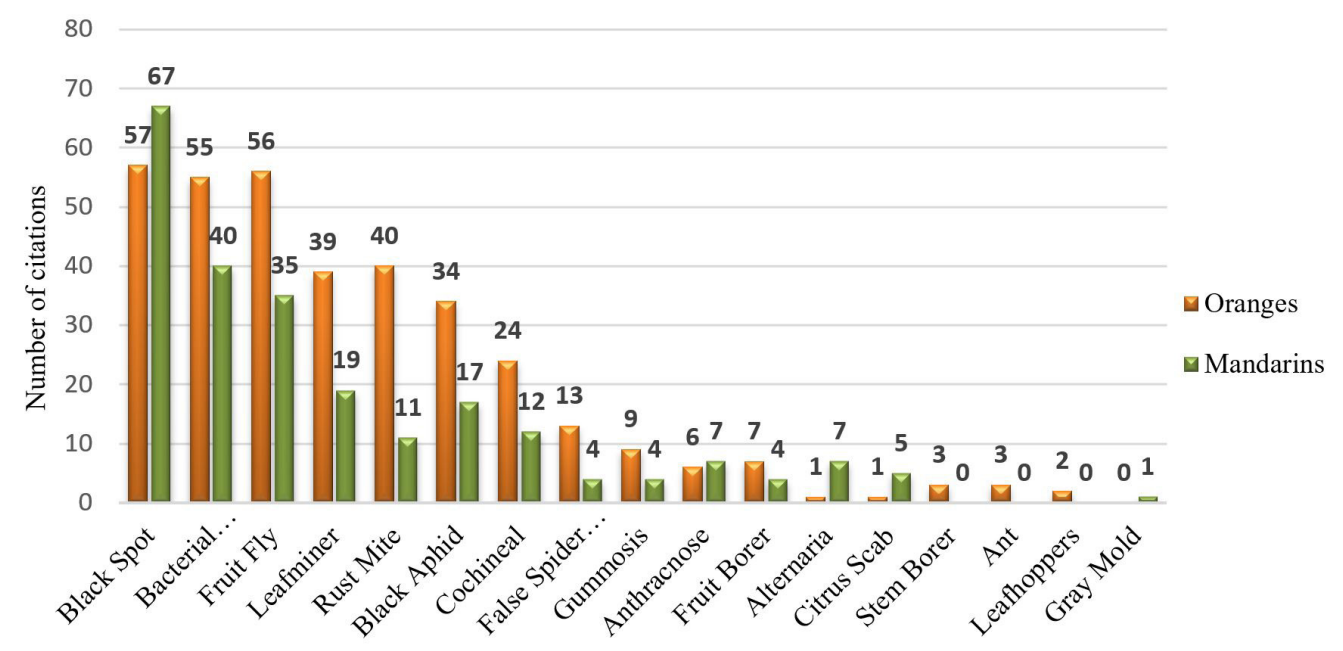

Figure 5. Number of citations of occurring pest on properties according to the productive focus: oranges or mandarins. State of Rio Grande do Sul, $2015(\mathrm{n}=163)$. 


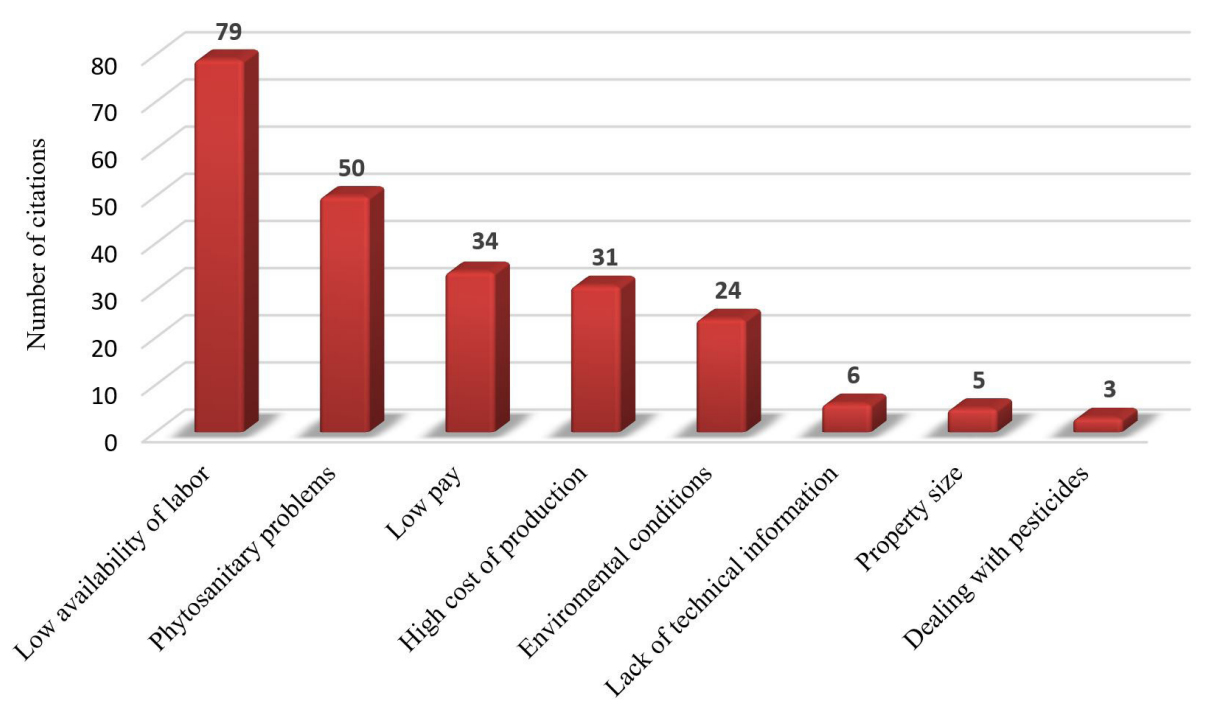

Figure 6. Number of citations per factor limiting citrus activity, according to the opinion of the farmers interviewed. State of Rio Grande do Sul, $2015(\mathrm{n}=163)$.

The similarity between the results can be explained by the variety observed in the orchards, where the plantation of only one variety per property rarely happens and, therefore, is the reason for the recurrence of the same phytosanitary problems by the respondents.

Citrus production in the region suffers from several problems which limit the citrus grower's production, in addition to making it more difficult for them to hold their place in domestic markets. It is of utmost importance to know and be aware about these limiting factors; information that can be used to develop strategies to encourage and promote citriculture through governmental agencies, as well as outreach programs aimed at educational activities, in order to promote local farming with the active participation of the small producers.

The citrus growers that were interviewed considered the main difficulties in production and the shortage of qualified labor was regarded as the greatest limitation to the current citrus production. This issue was cited by 79 of the interviewed farmers. The phytosanitary problems are the second most cited problematic factors, after the workforce issue, and it was reported as a limiting factor to the production by 50 individuals. In third place, the low yield obtained for the production, mentioned 34 times, followed by the high production cost (Figure 6).

Bonine \& João (2002) conducted a survey in order to characterize the difficulties in production faced by the citrus growers in Vale do Caí. The phytosanitary issues were considered as the greatest limiting factor according to the citrus growers, followed by the low wages that they receive for the fruit, in addition to the high cost of production, which shows that the factors that limit the citrus fruit chain in the state of Rio Grande do Sul haven't changed much, apart from the increasing shortage of workforce in the rural environment. It is known that the scarcity of labor derives mainly from the low rural succession observed. Among the factors listed, by the young people them selves, as the main causes for rural exodus are: the lack of autonomy and of a compatible remuneration, the exhausting and low paid-work, the lack of technical knowledge, social interaction and leisure are hampered due to work-related tasks over the weekends, in addition to the lack of parental encouragement and incentive for the young ones to stay in the country side (Gomes \& Schmidt, 2013; Faccin \& Schmidt, 2013).

\section{CONCLUSION}

Even though there is awide range of varieties in the citrus industry of the state, several prevailing characteristics could be noted, such as the ageing of the rural producers, the low education level, the typical family-operated farms and the uncertainties regarding succession, thus possibly jeopardizing the continuity of the citrus activity in the long run.

Among the noted concerns, the shortage of skilled labor for employment was the most cited concern by the citrus producers, and, in spite of all the difficulties, 
the citrus growers that were interviewed presented good technical knowledge, experience in the area in addition to demonstrating productivity levels that were close to the state's average.

\section{ACKNOWLEDGEMENTS}

The authors would like to thank the EMATER/RS offices in each of the municipalities, which actively helped them contact and collect information on the citrus growers for this survey, as well as The Plant Protection Service of MAPA, which has enabled the access of this research to more distant municipalities. The authors would also like to thank CNPq and CAPES for financial support.

\section{REFERENCES}

AGRIANUAL (2016) Anuário estatístico da agricultura Brasileira: culturas. Available from: $<$ http://agrianual. com.br/secao/culturas/citrus>. Accessed: 05 jan. 2016.

Bizzo HR, Hovell AMC \& Rezende CM (2009) Óleos essenciais no Brasil: aspectos gerais, desenvolvimento e perspectivas. Química Nova (32)3: 588-594. Available from: <http://www.scielo.br/pdf/qn/v32n3/a05v32n3. pdf>. Accessed: 05 jan. 2016.

Bonine DP \& João PL (2002) Estudo da cadeia produtiva dos citros no Vale do Caí/RS. Porto Alegre: EMATER. 47 p. (Informativo da EMATER/RS, Série Realidade Rural, v. 29).

Carneiro MJ (2001) Herança e gênero entre agricultores familiares. Estudos Feministas 9: 22-55. Available from: $<$ http://www.scielo.br/pdf/ref/v9n1/8602.pdf $>$. Accessed: 15 jan. 2016.

Duarte J (2008) Entrevista em profundidade. In: Duarte $\mathrm{J} \&$ Barros A (Orgs). Métodos e técnicas de pesquisa em comunicação. 2. ed. São Paulo: Atlas. 380 p.

EMATER/RS (2015) Levantamento citrícola. Porto Alegre: EMATER/RS.

Faccin OP \& Schmidt CEF (2013) Sucessão nas propriedades familiares integrantes de uma cooperativa agropecuária. In: Cotrim DS (Org). Gestão de cooperativas: produção acadêmica da Ascar. Porto Alegre: EMATER. 694 p. (Coleção Desenvolvimento Rural, v. 2). Available from:
$<$ http://www.emater.tche.br/site/arquivos/E_Book2.pdf $>$. Accessed: 14 mar. 2016.

FAO - Food and Agriculture Organization of the United Nations (2016) Production. Available from: $<$ http://www. fao.org/faostat/en/\#compare>. Accessed: 21 dec. 2016.

Godoy CMT, Pérez FIC, Wizniewsky JG, Guedes AC \& Moraes CS (2009) Juventude rural, envelhecimento e o papel da aposentadoria no meio rural: a realidade do município de Santa Rosa/RS. Anais do $48^{\circ}$ CONGRESSO SOBER, Campo Grande.

Gomes EJ \& Schmidt CEF (2013) Cooperativismo e juventude: as perspectivas de participação dos jovens das famílias associadas à cooperativa extremo norte. In: Cotrim DS (Org). Gestão de cooperativas: produção acadêmica da Ascar. Porto Alegre: EMATER. 694 p. (Coleção Desenvolvimento Rural, v. 2). Available from: $<$ http://www.emater.tche.br/site/arquivos/E_Book2.pdf $>$. Accessed: 14 mar. 2016.

IBGE - Instituto Brasileiro de Geografia e Estatística (2006) Censo agropecuário: agricultura familiar. Rio de Janeiro. 267 p. Available from: <http://www.ibge.gov. br/home/estatistica/economia/agropecuaria/censoagro/ brasil_2006/Brasil_censoagro2006.pdf $>$. Accessed: 17 jan. 2016.

IBGE - Instituto Brasileiro de Geografia e Estatística (2015) Levantamento sistemático da produção agrícola. Available from: <ftp://ftp.ibge.gov.br/Producao_Agricola/ Fasciculo_Indicadores_IBGE/estProdAgr_201502.pdf $>$. Accessed: 25 dec. 2015.

IBGE - Instituto Brasileiro de Geografia e Estatística (2016) Lavoura permanente por Estado. Available from: $<$ http://www.ibge.gov.br/estadosat/temas.php?sigla=rs\& tema=lavourapermanente2015>. Accessed: 21 dec. 2016. João PL (2010) A citricultura no Rio Grande do Sul. In: FEPAGRO. Indicações técnicas para a citricultura do Rio Grande do Sul. Porto Alegre: Fepagro, p. 15-16.

Mera CMP \& Mielitz Netto CGA (2014) Envelhecimento dos produtores no meio rural na região de Alto Jacuí/RS e consequente migração para cidade. Estudos Interdisciplinares sobre o Envelhecimento 19(3): 759-774. Available from: <http://www.seer.ufrgs.br/RevEnvelhecer/article/ view/42871>. Accessed: 16 jan. 2016.

Nava DE, Díez-Rodríguez GI \& Melo M (2011) Manejo de Pragas. In: Oliveira RP \& Scivittaro WB. Cultivo de 
citros sem sementes. Pelotas: Embrapa Clima Temperado, p. 265-288.

Oliveira RP \& Scivittaro WB (Eds) (2011) Cultivo de citros sem sementes. Pelotas: Embrapa Clima Temperado. 378 p. (Sistema de Produção, 21).

Oliveira RP, Scivittaro WB, Schroder EC \& Esswein FJ (Eds) (2010) Produção orgânica de citros no Rio Grande do Sul. Pelotas: Embrapa Clima Temperado. 296 p. (Sistema de produção, 20).

Panzenhagen NV (2004) A produção orgânica de citros no Vale do Caí/RS. Tese de Doutorado, Universidade Federal do Rio Grande do Sul, Porto Alegre.

Schäfer G, Bastianel M \& Dornelles ALC (2001) Portaenxertos utilizados na citricultura. Ciência Rural 31(4).
Available from: $<$ http://www.scielo.br/scielo.php?pid=S0 $10384782001000400028 \&$ script $=$ sci_arttext $>$. Accessed: 16 jan. 2016.

Ueno B (2011) Doenças. In: Oliveira RP \& Scivittaro WB. Cultivo de citros sem sementes. Pelotas: Embrapa Clima Temperado, p. 229-264.

Zulian A, Dörr AC \& Almeida SC (2013) Citricultura e agronegócio cooperativo no Brasil. Revista Eletrônica em Gestão, Educação e Tecnologia Ambiental 11(11): 2290-2306. Available from: <http://cascavel.ufsm.br/ revistas/ojs-2.2.2/index.php/reget/article/view/8700>. Accessed: 15 jan. 2016.

Received: November 15, 2016 Accepted: January 24, 2017 